While it is not usual to find metastases in rats with primary benzpyrene tumours, Oberling and II. and P. Guérin' have succeeded in obtaining them by injecting very large quantities of benzpyrene. Injection of $75 \mathrm{mgm}$. of benzpyreno will cause metastases in 50 per cent of rats. Oberling and Guérin consider that this is due either to the fact that large doses of benzpyrene lower the resistance of the organs, or that the tumour cells produced by large doses are more aggressive and proliferative.

In our cases, the animals show. ing metastases did not come into contact with benzpyrene. It must be assumed that both the tendency to metastasis formation and the organ affinity in our tumour strain is based upon a peculiar property of the tumour cells themselves.

Department of Radiobiology, L. Halberstaedter.

Cancer Laboratories,

The Hebrew University, Jerusalem.

June 30.

1 Amer. J. Canc., 35, 103 (1939).

J. Puth. Bact., 47, 501 (1938).

- Tattre, 143, 228 (1939).

- Bull. Assoc. franf. Etude Canc., 32, 193 (1939).

\title{
Lethal Action of Alpha-Rays on Sea-Urchin Eggs
}

Whes unfertilized eggs of sea-urchin, Pseudo. centrotus depressus (A. Agassiz), aro inseminated immediately after tho irradiation with gamma- or beta-rays of radium, the time of their first cleavage is prolonged roughly in proportion to doses ${ }^{1}$. This phenomenon has the same tendency to that already reported by Henshaw ${ }^{2}$ and others, who used roentgen ray's and ultra-violet light. Recently, we have studied the effect of alpha-ray irradiation and obtained quite different results.

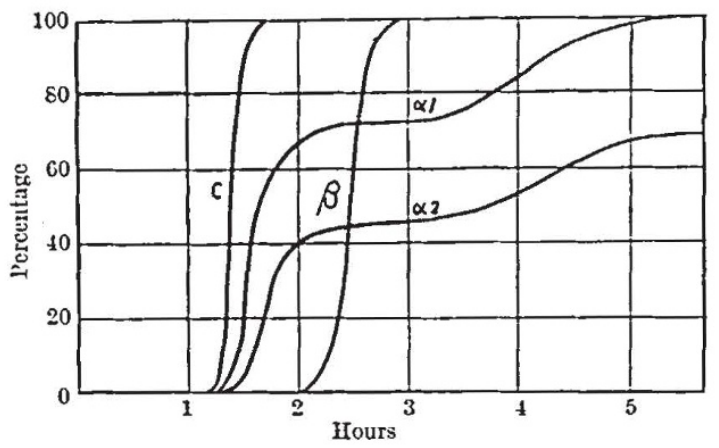

Fig. 1.

Curves showixg the percentage ixcrease of eggs IN TWO-CELL STAGE AFTER INSEMINATION.

$c$ : CONTROL; $\beta$ : IRRADIATED WITH BETA-RAYS (30,000 $r$ IN ONE HOUR); $a_{1}$ AND $\alpha_{2}$ : IRRADIATED WTTH ALPHA-RAYS (48 NC.-SEC. IN 10 SECONDS AND 145 yC.-SEC. IN 1 MINUTE).

The following experiment was made on the eggs of sea-urchin, Strongylocentrotus purcherrimus (A. Agassiz). Eggs were carefully placed in a single layer in a small dish, $7 \mathrm{~mm}$. in diameter with a thin bottom

of collodion film, less than $1 \mu$ in thickness. Under the dish a piece of glass with radium $C^{\prime}$ was placed at the distance of $5 \mathrm{~mm}$. As the range of alpha-rays of radium $\mathrm{C}^{\prime}$ in water is $60 \mu$, taking into consideration the absorption of the air and the specific gravity of eggs, the alpha-rays are estimated to penetrate into the eggs as far as $51 \mu$. The diameter of the eggs is about $90 \mu$. In every experiment the intensity of radium $\mathrm{C}^{\prime}$ activity was measured by electrometer and the dose is expressed by millicurie-second, considering the decay of radium $\mathrm{C}^{\prime}$.

Fig. 1 indicates the increaso of the percentage of eggs in two-cell stage produced by first cleavage with the lapse of time after insemination. Curve $C$ shows control, curve $\beta$ a case of beta-ray irradiation, and curve $\alpha_{1}$ and $\alpha_{2}$ two cases of alpha-ray irradiation. Tho eggs irradiated by beta-rays (curvo $\beta$ ) take some time to begin cleavage and their cleavage goes on slowly, but the tendency resembles control. Small doses of alpha-ray's produce no effect on tho cleavago timo. Even after larger doses of alpha-rays (curvo $\alpha_{1}$ ) the beginning time of the cleavage is almost the same as in control. (A very little prolongation shown is considered as the effects of beta-rays accompanied by alpha-rays.) Moreover, in this case tho cleavage proceeds very fast at the beginning, but seems to stop when a certain percentage of cleavage is reached, while after several hours it goes on very slowly again. Thus in the case of alpha-ray irradiation, some eggs take the ordinary course of cleavage, while in others the cleavage is delayed. With the increasing doses of alpha-rays, fewer cases of the ordinary cleavage are observed (curve $\alpha_{2}$ ), and some eggs stop cleavage absolutely. Even the eggs producing fertilization membrane by insemination with normal sperm stop cleavage, and from about one hour after the irradiation they gradually disintegrate, as is shown in Fig. 2. This disintegration phenomenon ean be seen in the same way in unfertilized egg. This is death caused directly by alpha-rays.

Wo are indebted to Prof. II. Nagayo, Dr. H. Yamakawa and Dr. W. Nakahara for their kind advice and encouragement. Jrivo Mrwa.

Radiological and Pathological

\section{Hisao Yamasirita.}

Kazuo Morr.

Divisions of the Japanese Foundation

for Cancer Research, Tolkyo. May 24.

1 Jiwa, Yamashita and Mrori, Gann, 33, 1 (1939).

'IIenshaw, P.S., Amer. J. Roent., 27, 890 (1932). 